\title{
I Treat Him as My Own Son
}

\author{
Jiaying Xiao
}

\section{Interview with Mr. QB's Father}

QB, male, born in 1994. The only child in the family. Grade IV intellectual disability. Graduated from a special education school (Shanghai Primary Vocational and Technical School of Changning District) in 2012. Started working at Shanghai Papa John's in 2013.

Interviewee: QB's father

Interviewer and writer: Jiaying Xiao

Interview dates: September 25, 2016 and March 4, 2017

Interview place: Shanghai Electric Power Hospital ${ }^{1}$

\section{Forced to Drop Out After Two Years of Regular School}

Q: When did you marry QB's mom?

QB's father: It was the second marriage for both of us. We got married in 1999 when QB was six. He is 23 now.

Q: Did you know that QB had a disability when you got married?

QB's father: I didn't. He was pretty normal then, but maybe that's because he was still young and his disability wasn't showing yet. And he didn't exactly physically or verbally abuse anyone, nor did he have any physical disability. Everything seemed perfectly normal with him. His grandma would take him to preschool every day after

\footnotetext{
${ }^{1}$ OB's father was taking care of his mother-in-law in the hospital. Therefore, the interviews were held in the hospital during pauses when he was doing his tasks.
}

J. Xiao $(\bowtie)$

Fudan University, 220 Handan Ro., Shanghai 200433, China

(C) The Author(s) 2020

403

W. P. Alford et al. (eds.), An Oral History of the Special Olympics

in China Volume 3, Economy and Social Inclusion,

https://doi.org/10.1007/978-981-15-5005-8_12 
breakfast. We lived next to Zhongshan Park and he went to Yuyuan Road Preschool. After dropping him off, his grandma would walk around the park for exercise and pick him up later in the day. His mom and I both worked and we didn't have a lot of time for him.

He went to No. 2 West Yan'an Road Elementary School which was close to Zhaohua Road and close to where we lived. His disability hadn't been detected then because the curriculum was as simple as one, two, three. When he was in second grade, his teacher found that he couldn't keep up in English and math and couldn't do single-digit additions. You couldn't tell that he had intellectual disability just by looking at him, but the teacher suspected that he had it because he couldn't solve the most basic math problems. So he asked us to take him to Changning Psychiatric Disease Prevention Center for an IQ test.

The test results showed his IQ to be a little over 52 points, which is almost 5 points lower than that of average people. So we took him to the hospital to test his brain functions and his brain does function on a level lower than that of average people. No wonder he couldn't keep up at school.

So the school asked him to drop out and made it clear that it didn't want him, the reason being that the curriculum would get more difficult and anyone who couldn't keep up in intellectual ability would fall behind further. So he dropped out and went to the special education school of Changning District. There's a special education school in each district and the one in our district was close to Xianxia Road.

I don't know how he got the disability or what had happened. My wife has no disability. I am telling the truth since I have nothing to hide. When we got married, I heard from her relative that she isn't the biological daughter of the mom who is now hospitalized. She was adopted and her biological mom had some mental problems. But she has never seen her biological mom ever since she was adopted, neither have I. She was born in Malu in Jiading District and adopted by my current mother-in-law when she was two. Only my mother-in-law knows where the biological mom is, but my mother-in-law is still alive, so my wife can't very well reunite with her biological mom. I can't take her to look for her biological mom until the adopted mom has passed away. Her biological mom shouldn't be that old, since she is 46 this year. Having said that, I believe that genes were at play. Her biological mom passed it to her and she passed it to her son, from generation to generation, which is perfectly normal. I definitely don't have any problems myself, and he isn't my biological son anyway. (Laughing)

Since you came to talk to me, I won't hide anything from you and will tell you everything instead. My current mother-in-law isn't very nice to my wife. She often yells at her, and is very short-tempered and aggressive, insisting on everything being the way she wants it. Sometimes my wife will tell me that she knows she is from Jiading and would like to look for her biological mom, and I will say, "How can you do it now? And once you find her, which mom are you going to stick with? You will have to wait till your adopted mom has passed away before you go looking for your biological mom." I figure that her biological mom is only in her seventies. According to her relative, she also has an older brother and older sister from the biological mom. 


\section{A Top Student in Special Education School}

Q: Did you struggle about it before switching his schools? Was he willing to go to another school?

QB's father: He didn't understand. How could he since he was only nine?

Q: So he switched schools because you switched it for him?

QB's father: Right. We dropped him off and picked him up every day. The school was where Tianshan Road crosses Xianxia Road and easy to get to from where we lived. There's a bus Line 127 with a stop close to where we lived, at the intersection of Yan' an Road and Dingxi Road. So we would take the bus to the terminal stop and the school was right across the street. We rode the bus to take him to school. Since there were three adults in the family, whoever had time would take him. When he was in fifth or sixth grade, he would ride the bus himself. We just let him do it, and he came home by himself, too, and never had any problem on the way.

The special education school offers 9 years of schooling. QB was in a combined class of first, second, and third grades, because there were not enough students to have three separate classes. But the curriculum was divided into first, second, and third grades even though there's only one teacher covering everything. So the three grades were in one classroom, and the higher grades were in other classrooms. After third grade, he moved to another class which was called middle grade. Basically, the 9 years were divided into low, middle, and high grades.

The school had its own textbooks. The teachers would compile some materials and distribute photocopies to the students. There were also Chinese books and math books purchased from the general market. Older students would be given some homework and learn some arts and crafts including drawing and paper cutting. The most basic things were taught, like simple Chinese characters and math. The teaching was tailored for individuals. If you were more like an average person, you were taught more difficult things. But if you had cerebral palsy, you wouldn't be able to learn anything anyway. But in QB's class, since there were not many kids, the kids were all grouped together and the teaching was only slightly differentiated.

Q: Did he have homework? Did you help him with his homework?

QB's father: He did have homework that had to be handed in and checked by the teacher, just like what happens at regular schools now. He had to do additions, subtractions, multiplications, and divisions, and there were parentheses, and the most difficult part seemed to be $\pi$ which I had never learnt myself. (Laughing) I saw him working on that as part of the homework. He did well at academics and was able to keep up. There wasn't a lot of homework. He had to copy a text sometimes or a poem other times, to practice calligraphy. They weren't really expected to write any essay on their own.

We did tutor him at home. He would be allowed some rest first, then he was asked to take out his homework. Parents were required to sign off on the kids' completed homework every day. We would teach him if there was anything he didn't understand, but he understood pretty much everything, since he was taught only very simple things. He finished second grade at No. 2 West Yan'an Road Elementary 
School and what he had learned there was more difficult than what was taught at the special education school, because kids at the special education school had ID and difficulties absorbing new things. Comparatively speaking, my son has a high IQ. But on the whole, what was taught at the special education school wasn't that different from what was taught at regular elementary schools.

Q: Were there tests at the special education school?

QB's father: There were, like there were tests at regular schools. The school also assigned homework for summer and winter vacations. There were both midterms and finals. To prepare for midterms, the teacher would give them sample questions and he would finish them at school instead of bringing them home. The scored tests had to be brought home to be signed by parents. He did well on the tests, scoring above 80 points and sometimes above 90 points.

The school organized activities too. Yao Ming came to teach them basketball. QB was on the school basketball team, so he got a set of No. 5 clothes from Yao Ming. Some popular singers also visited the school to interact with the students. Yao Ming visited special education schools a lot. At the primary vocational school that my son went to later, Yao Ming came too and would bring pens and notebooks for everyone sometimes. Their school often had celebrity visitors.

Every time he saw Yao Ming, QB was happy and excited and would tell us all about it, saying "I saw Yao Ming" or "Yao Ming came to our school today."

The school basketball team often had activities. There were either 16 or 18 kids on the team, and what happened was that if school ended earlier on a certain day, the PE teacher would give them some training. The training wouldn't be long, lasting 40 or $45 \mathrm{~min}$ and never more than $60 \mathrm{~min}$. And he could just shower at home after the training. It was good for him. The school was a good one, because it tailored its teaching and activities to the kids' IQ and tried to train the kids to be self-dependent for when they became part of society later on.

Q: Did they have basketball games?

QB's father: At school, the kids would just play against each other in two teams. Sometimes they would play against teams from other schools, so they did have some games.

He liked basketball and would watch whatever basketball games showing on TV. He bought a lot of NBA posters and we had a lot of them at home. The posters were very expensive, costing more than 20 yuan each and featuring all the NBA stars.

Q: Would you talk to him about basketball?

QB's father: I don't understand basketball. He liked it and would watch games on TV by himself.

Q: Did the school organize any other activities?

QB's father: It's a 9-year school, and it did organize field trips. QB was young and didn't get to go on all of them. But at least he went on some trips, whereas kids with cerebral palsy couldn't be taken on any field trips at all. They went to so many places, including Shanghai Library, Century Park, the Oriental Pearl, Dongfang Oasis, and Shanghai Science and Technology Museum. Basically, the school took them to all of the places worth visiting in Shanghai, to try to develop their intellect and expose them to society. QB doesn't look so bad now, I will have to admit that. Maybe there's this 
gene on his mom's side of the family, and my wife hasn't had many years' schooling herself.

Parents didn't go on the field trips because they would have had to pay for entrance. The teachers took the kids and entrance was free for them since activities by such schools were kind of sponsored by society. The field trips usually lasted a whole day and he would bring bread on the trips. Sometimes the school would provide bottled water and bread as lunch. They would leave in the morning and come back at night, the school would give us the schedule and we would wait in front of the school at night to pick up the kids. The school organized such trips quite often.

The kids were always happy on field trips. QB would come home and tell us what he did on the trips, like he would tell us what he saw at the Oriental Pearl.

After he graduated from the special education school, he moved on to the primary vocational school on Dingxi Road, which was specifically for kids like him. It's actually connected with the special education school, and students graduating from the special education school were transferred directly to that school.

He learnt about the restaurant business at the vocational school, like how to place glasses on the dining tables, how to fold napkins into ribbons, and how to place chopsticks. The school also taught simple cooking like spicy tofu and five-spice shredded pork so that the students could acquire some skills. He had to practice at home what he had learnt at school. Sometimes he would get some tofu or shred some pork to cook spicy tofu or fish-flavored pork at home. We tasted his cooking and it was decent. The teacher taught according to recipes and provided more ingredients than we had at home. He hasn't cooked after graduation. He works now and has no time to cook.

Q: Was it easier or tougher going to the vocational school than to the special education school?

QB's father: The vocational school was nice and easier than that 9-year school. There was no homework to bring home. There was an experience class followed by academic classes, and one of the academic classes was set aside for the students to do homework in class so they wouldn't need to bring any home. Even if they couldn't finish in that class, they still wouldn't have a lot to bring home.

There were a lot of activities at the vocational school too, including field trips to places like Shanghai Museum and activities with other schools. There was once a joint singing competition with a school from Jing' an District and a program to help kids at the school make friends with students from two schools in Yangpu District.

He liked everything the school organized and would come home and tell us all about it. I asked him if he was happy and the answer was always affirmative. As parents, we are happy whenever the kid is happy. What else can you expect of him? You can't be demanding with kids like him because he will have to disappoint you, right? What other choice is there?

Q: How was his interaction with schoolmates?

QB's father: It was good. The teachers liked him and he cooked well. In addition to spicy tofu and five-spice shredded pork, he could also make chive pancake, green onion pancake, and other pancakes. After the teacher had finished teaching and everyone had finished cooking, he was in charge of the kitchen key and wiping down 
the counters. He got along well with everyone at school and the teachers all liked him.

Q: Does having the kitchen key mean that he was in charge of opening and closing the kitchen?

QB's father: What happened was that the teacher was done after finishing cooking and the students were responsible for cleaning up. Sometimes my son would ask a couple of classmates to use some dish detergent and a mop to wipe down the counters and to wash all the pots. Then he would put away the pots, lock up the kitchen and put the key in a safe place since he was in charge of the key. He was in charge of all the ingredients and kitchenware, and the teacher was very nice to him.

We lived close to the school, so I liked to stop by to talk to the teachers and ask how QB was doing. The teachers all said he was doing great and they all liked him. There was this teacher who even gave him a jacket on his birthday which cost more than 100 yuan. At Papa John's where he works now, the store manager and two other managers like him a lot and are always calling on him for help.

Q: Did QB have good friends at school?

QB's father: He had several and was close to two of them and is still connected with them by cell phone. One of them is called Y who was his classmate from elementary school. He lived closer to the school, near Yaohong Road at North Xingjing. They have always kept in touch and often check up on each other by phone. Y calls us at home too to ask whether QB is busy or doing well. It's nice to have such a friend whose disability seems to be of a lesser degree than QB's. They also went out together.

I believe he works at KFC which was arranged by the school too. At the school, there were four kids whose disabilities were not that bad. My son was one, there was $\mathrm{Y}$, and another... I was the one who went to almost every parent-teacher conference. There was hardly any kid who could pass off as an average kid and quite a few kids with cerebral palsy.

Q: Did his friends ever visit him at home?

QB's father: No.

Q: Has he ever been to any of his friends' place?

QB's father: He has. He hadn't graduated yet and was either in seventh or eighth grade. After school, he just went to the friend's place and was nowhere to be found. Not seeing him at home, I called his school and was told that he had left school a while back. I was given the teacher's cell phone number and called the teacher. They said that he had gone back home but I said I didn't have him at home. The teacher panicked then and started asking around for me and called that other student's house. So what happened was that that student's dad came to pick him up and insisted that my son go to his place for dinner. QB just went without calling to tell us about it. We were panicking waiting for him to come home. It was dark already and past dinner time. The teacher called that student's house and found QB there. The teacher then called me and I asked for that student's address. I was getting ready to go there when my son came back.

Q: He knew his way back?

QB's father: He knew which bus to take to come home. That's the only time he went to a friend's place. 
Q: Did he just not want to do it again or did you forbid him from doing it again?

QB's father: It's not us. We never did that. After he graduated from school, we have always supported him to go out and have fun instead of staying home all the time.

\section{Only Appearance of the Biological Father in Eighteen Years}

Q: Are you in contact with his biological father?

QB's father: Never. We have never been in contact with him since we got married, which was in 1999. It has been 18 years, and his biological father only showed up once. QB was still in the special education school and he took him out for a day.

Q: Did his biological father know about his intellectual disability?

QB's father: He didn't. There's a neighbor who might have been related to QB's dad or might have just been a neighbor. He has since moved to Xujing where all the low-rent housing is in Shanghai. He was the matchmaker for QB's parents. The dad liked to gamble and never took care of the family. QB's grandpa had liver cancer, cirrhosis in fact. He passed away 20 years ago. After he checked out of the hospital, he asked QB's mom to get a divorce saying that she shouldn't continue living with QB's dad because he was never home and was gambling somewhere all the time. So that's how it went down. Even while the grandpa was bedridden, QB's dad was dragged to the court for QB's mom to divorce him. After the baby was born, he only saw him once, and he didn't even visit the mom at the hospital recovering from the birth. He was out there gambling away. With someone like him who loved gambling, if he won, he could bring some money home, but if he lost, he would be in no mood to take care of the family or the kid. How could he take care of anyone or anything when he had no money in his pocket?

Q: So QB has no emotional bond with his biological father and no contact?

QB's father: No, no, no emotional bond. He was still in the special education school and the dad took him out to buy toys. Back then the popular toy was the scooter, with two wheels that you pushed with one foot. It's not popular anymore. So the dad bought that for him and ate with him. That's the only time. And he hasn't shown up again since.

Q: Did QB come back that day to talk about his biological father?

QB's father: What did he know? He knew nothing. Ever since my wife and I got married, he has been calling me "Dad." He didn't know that I am not his biological father.

Q: And he still doesn't know now?

QB's father: Now he knows. It was explained to him. He was still young back then, graduating from the special education school and about to transfer to the vocational school. His grandma told him. I treat him well and I have always taken care of him.

Q: Had you planned beforehand to wait for him to graduate to tell him?

QB's father: We hadn't planned. His grandma took it upon herself to tell him. I hadn't wanted to tell him, but his grandma told him. After her revelation, he seldom 
calls me "Dad." He knows and he is getting older. I had planned to wait till he was old enough to understand to tell him. But his biological father must have told him when he took him out that time, especially since he took him to where he lived.

Q: So he probably understood some of it back then?

QB's father: He should have if he was really told back then.

Q: Had his grandma already told him when his biological father took him out that time?

QB's father: No, not yet. His dad must have told him that he is his dad and introduced him to those in his family, since they went to his place. He lived on Luban Road, underneath Lupu Bridge, one of those old places. Ever since his grandma told him, he has almost never called me "Dad."

Q: So you are not as close as you were before?

QB's father: Right. He understands now since he is older.

Q: Does it bother you?

QB's father: Not really. He isn't my biological son anyway, so I am okay. I will still do what I am supposed to do, like I have always done. I will try to fulfill my responsibilities since I still see him as my own son.

\section{A Stable Job and Close Co-Workers}

QB's father: After he graduated from school, he stayed home for close to 2 years. He would sleep in and get up and brush his teeth for lunch. There was no computer at home yet, so he would watch TV till 1 or 2 a.m. It was too late and not good for his brain. So I discussed with my wife and decided to find a job for him. It would be good for him since he would be able to support himself instead of lazing around at home. So we sought help from the school and found him this job of his.

Q: The school didn't arrange any job for him upon his graduation?

QB's father: No, the school didn't arrange jobs for the students. It asked them to look for jobs themselves. If you couldn't, then the school would give you some referrals. There were several designated teachers who would lobby for restaurant internships for the students at places like KFC and McDonald's, and if the students did well at the internships and the managers liked them, they could be formally hired. The store would just tell the school that it would like to hire a particular student.

Like my son, he started with Papa John's and has been with them ever since. There were some disruptions in between, but he has been at Papa John's for a total of 5 years. He does well at his job and everyone at the store likes him. The truth is that he is not the violent kind who physically or verbally abuses others. He isn't that kind. He listens well and does whatever the manager asks him to do, so everyone at the store likes him and orders him around.

We didn't get him a disability certificate after he graduated from school. After 3 months on the job, Papa John's asked him for the certificate saying that he couldn't continue working there without it. So we went to Changning Psychiatric Health Center to apply for one and didn't succeed. He was tested at the center and asked to 
read characters from pictures and differentiate colors. His score was two points higher than the standard, so he didn't qualify for the certificate. He had to stay home and that lasted almost 12 months. Originally you were allowed to apply for the disability certificate twice a year, then it was reduced to once a year. That's why he had to stay home for almost a year between applications. During that year, Papa John's asked him to go back to work even without the certificate saying that it was willing to wait on it, so I asked him to go back to work. So he went back to work and didn't do particularly well and had to come back home after about 2 months. We were able to get him the disability certificate the second time we applied. After that, he went back to Papa John's and has been working there ever since.

Of course, without a disability certificate, he definitely couldn't have continued working at Papa John's. He is doing okay now. His IQ is indeed a little lower than that of average people. But look at him, he watches TV, plays on his cell phone, and gets on WeChat without anyone helping him. I don't know what to do with WeChat, but he knows. But maybe it's because he has been exposed to society and his social circle is different now. He hadn't known so many things when he was staying home.

Q: He didn't get a disability certificate when he was young?

QB's father: He was going to school and no one had thought of getting a disability certificate for him. Some kids at his school did get the certificate right before graduation. There were only a few kids from his school who went on to work after graduation. The majority just stayed home. Even a large percentage of the healthier ones couldn't get jobs, like those with ADHD who couldn't stay still for anything. There's a kid who couldn't stop for one single second all day long. There were also kids with cerebral palsy who couldn't take care of themselves, drooling all the time at school and having no control over bathroom needs. There were many kids like that at the school, and comparatively speaking, QB was normal.

Q: After he stopped working at Papa John's, what did he do at home?

QB's father: There's nothing to do at home. He would watch TV or take a walk when he was in the mood. He didn't cook or do laundry. We did all of the chores.

Q: Did you not ask him to help around the house?

QB's father: We didn't, and he didn't want to help anyway. He would pour cooking oil into the pan, and once the oil started boiling, he would throw the vegetables in while staying way back, and the oil ended up splashing everywhere on the counter. So we didn't want him to cook anymore. When he was staying home, we asked him to wash his own socks. He did it at first, then he didn't want to do it anymore no matter how we asked him, so we gave up and have been doing it for him since. Now it's even harder to ask him to do it, and he doesn't have time anyway since he works.

$\mathrm{Q}$ : Is there any other job your son wants for himself, and does he have any plan for his own future?

QB's father: No. He believes he is doing well at the current job. I asked him how he was doing and he said he was doing okay. I went to the store to ask the manager, too, and the manager said that everyone likes him. Both managers said that he is in good hands at the store. I came back home and asked him, "Do you really want to work there? If you do, you do. If not, don't force yourself because you won't be 
happy, and you are still young. So are you sure you want to work there?" He said "Yes." He really likes that job (see Fig. 1).

What does he do there? He works in the kitchen in the back. He makes pizza dough, at least I think that's what it's called. And he spreads ketchup on the dough and lays on some beef. If someone orders a fruit plate or drink, he will put a small

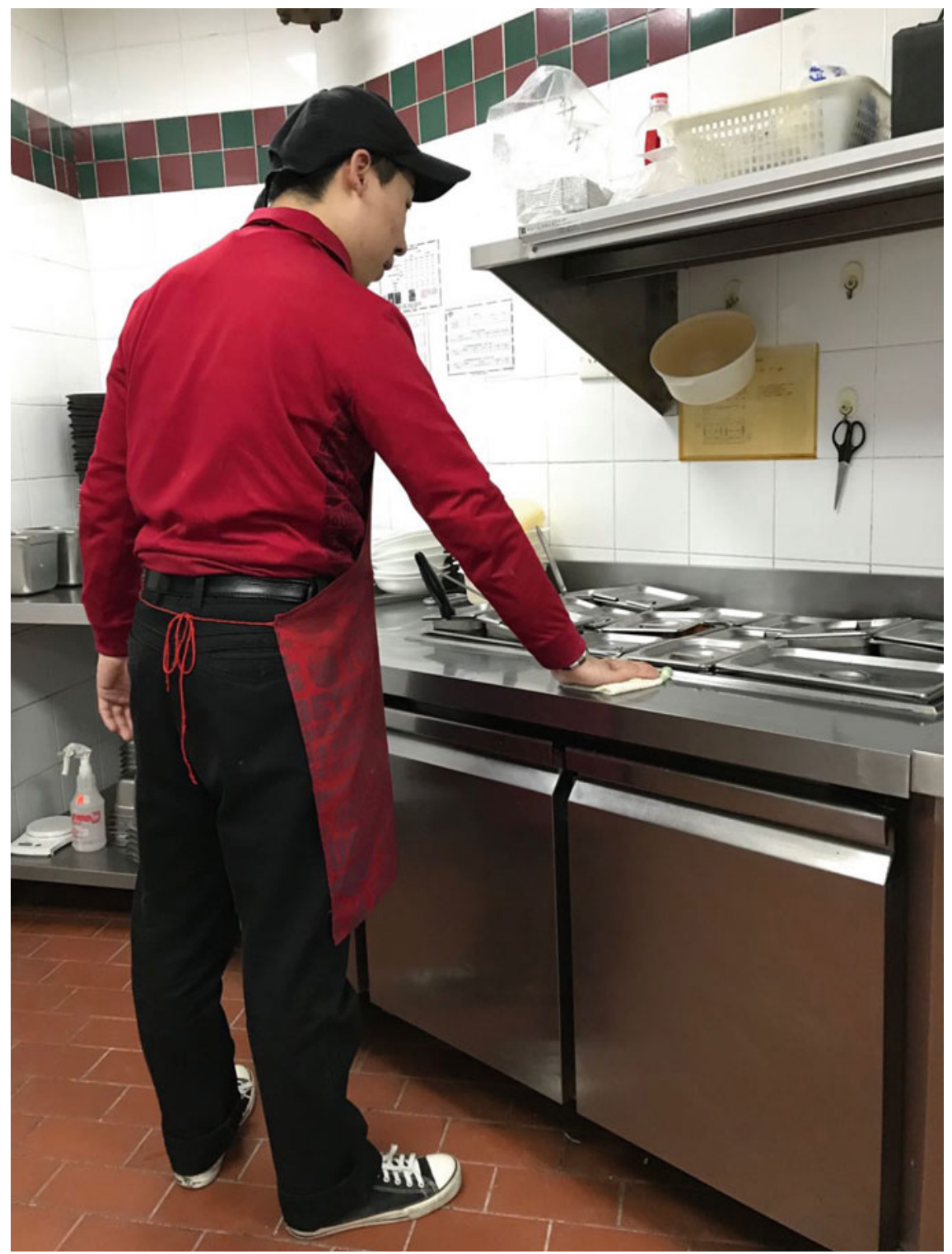

Fig. 1 Mr. QB at work 
umbrella on the drink or a slice of lemon. That's what he does. He doesn't work in the dining area. He stays in the back as kitchen help.

Q: How does he get along with his co-workers?

QB's father: He gets along well and everyone likes him a lot. He has no problem with any of the co-workers, according to the manager. I often chat with the manager and call her up sometimes. Her last name is Huang. The one before her was a guy whose last name is Liu. I talk to her often, texting her during Chinese New Year or calling her up sometimes and asking how my son has been doing recently. She always replies, "Everything is good. We all like him a lot. Don't worry, I will take care of him."

He was asked to work OT on almost every holiday including Chinese New Year. For the Chinese New Year this year, he worked OT all 3 days. He also worked OT on October 1 and New Year's Day. The manager told me, "Why would you have him stay home? If you let him come to work, he can earn 3 days' pay. That's pretty good, isn't it?" The manager takes good care of him, too. Sometimes he is asked to help with things that are not part of his job, and he is very eager and happy to help.

It's good that he is happy at what he does. The pay isn't high, but at least it's enough for him to support himself. Now he makes 2,500 or 2,600 yuan per month. The truth is that if he doesn't like this job and wants to quit, we will have a hard time finding him another job. Who would want to hire him the way he is? There's no way any of those regular workplaces, stores or restaurants would hire him. So I am grateful to the school for this job. The school knew that jobs don't come easy to people like him and it did its best to set things up for them, and workplaces that do hire people like him can enjoy some tax benefits.

The school had two designated teachers who lobbied for places to hire them. For example, there were a number of students graduating in a certain year, so the two teachers would visit workplaces and arrange for the students to interview with those cooperating workplaces to make it easier for the students to get jobs. It's still like that now. The school is still in existence. It's called Changning Primary Vocational School and is specifically for kids graduating from special education schools. It's located on Dingxi Road.

Q: What does he do after getting paid? Is he in charge of his own pay?

QB's father: The pay is deposited into the bankcard. We are in charge of his pay. Every month after he gets paid, we will give him 400 or 500 yuan, and he can use it to buy drinks on hot days.

He takes Tuesday and Wednesday off. On the days he works, we will cook for him. His mom doesn't cook in the morning. I do it, since I am retired. Before my mother-in-law was hospitalized, I did almost all the cooking including breakfast for him. The routine with him is that he eats at home from 9:30 to 10 a.m. We will get his food and clothes ready for him, and he will leave for work right after he finishes eating. He starts work at 11 a.m. and he prefers to leave at 10 a.m. He walks from home to Jiangsu Road where there's bus Line 01 and Line 02 , both of which go to Caoyang Road. He knows where to get off to walk the shortest distance to the store. He normally arrives early and has never been late for work. He usually arrives at 10:40 or 10:45. If we have no packed lunch for him, he will eat out. There are a lot of 
places to eat next to the store, like hot pot, fried wontons, and curry rice. If he feels he has no appetite for homemade food, he will eat out himself. We will have dinner ready for him when he comes back. It's like that every day. We do his laundry for him. He will watch a little TV after he gets home and then go to bed.

Q: Was there a big difference before and after he started working? Has he become more talkative?

QB's father: He has matured a lot. When he wasn't working, he seemed to be a little autistic and not inclined to talk. And he seems to have changed completely since he started working. After all, he is exposed to society and party of society. He sees a lot and his mentality has improved a lot. When he gets home, I will ask him, "How did it go today? Are you tired?" And he will say, "Not tired, I am okay." "Were you busy today?" "Nope." "What did you do today? What did you have for lunch?"We will carry on conversations like that. Sometimes he eats out when he doesn't bring food from home. So he has become more talkative. Whatever he sees or hears at the store including gossip, he will come back and tell us. There are employees coming and going at the store, and he will tell us about it including their names.

Q: So overall, having a job has been good for him.

QB's father: Of course, definitely. We used to not have a computer at home, so he spent all his time watching TV. He wouldn't go to bed till midnight and he would spend the morning catching up on lost sleep. He would skip breakfast and get up at noon. His schedule has become more regular since he started working. It used to be erratic when he was staying home, so I was determined to send him out there to work. I was looking for a job for him everywhere. I went to China Mobile, which is close to where we live, to a telecommunications company, to a bus company, to the subway company, and to Changning Cable TV where there were openings for repairmen for cable boxes. I took him to all kinds of interviews and it was no use, no one wanted him.

Q: So eventually he got this job with help from the school?

QB's father: Right. There were openings for subway security back then and I took him to the interview in Bashi Building close to Dapu Road. He wasn't hired, not even as a security guard.

\section{Treated Better Than a Biological Son}

QB's father: We make effort to talk to him, to take him out including eating out, because we want to help develop his intellect.

Before he started working, we would take him out for a walk after dinner on a hot day. Kids like him need to see the world instead of being locked up at home all day long. We would take him to the supermarket and ask him to check out what he liked, then we would give him money so he could pay for it. We often taught him how to interact when we took him out. I still had the car then, so we often drove when we went out. I used to drive the company car home and drive it to work. 
We also encouraged him to watch TV. We have a small room measuring a little over eight square meters. He has that room to himself where he has his own TV. Now he also has his own computer there.

That's the best we can do. Neither his mom nor I are highly educated. I graduated in 1973, and you know what happened to those graduating around that time. The Cultural Revolution was still going on, and there was no school to go to. Whoever graduated was counted as having graduated from junior high school, even though some were just elementary school graduates, and it wasn't exactly advanced education.

Q: When did you buy him the computer?

QB's father: It has been a while, 6 years actually. He wanted one, so we bought him one. We had no idea what to do with the computer, so he figured it out himself.

Q: Did he install all the programs after you bought him the computer?

QB's father: He did it himself since we didn't know how. The computer cost 2,800 yuan. The battery died yesterday, and I haven't got around to buying a new one for him. I don't know where to get a new one. The brand is Lenovo, so I probably have to go to a Lenovo store, right? I may not even be able to get a replacement since the computer is really old. There's no power display now even when the computer is plugged in.

$\mathrm{Q}$ : Is his computer a desktop?

QB's father: It's a desktop. Oh no, it's a laptop.

Q: Six years is a long time.

QB's father: Right. Computers get outdated so fast nowadays. It's a laptop that came with a free bag.

Q: So basically, you give him whatever he wants?

QB's father: Basically. When he was going to school, he dressed and ate better than his schoolmates. I figured that because he is not my biological son, if I dressed him just so-so, the neighbors would think it's because I am not his real dad. So I usually bought fancier things for him. It's like that even now. He dresses better than the average person, and his shoes are all name brand ones like Nike and Adidas. The neighbors all tell me that my son has been wearing name brands ever since he was young. They all know I treat this son very well even though he is not my biological son. If I didn't treat him well people would judge me, especially since he is not my biological son. And how would his mom have felt? She would have felt that I didn't treat him well because he is not my biological son. I am sure she would have felt that way.

I make sure that he not only dresses well but also eats well. He doesn't eat leftovers now and is very picky about what he eats. His mom will cook braised water eel and pork for him. He will eat it at home and bring some to work. If he comes home at night and is still served the same dish, he will not eat much. If the dish is saved in the fridge till the next day, he won't even touch it, no matter how good it is. Now we only pack quality food for him to bring to work. The manager commented last time on how good his packed lunch was. There are some employees at the store who are not from Shanghai, and what do they eat? They have no time to cook themselves by the time they get home at nine or ten at night. And a lot of parents will just pack leftovers and put them in the fridge for lunch the next day. We cook fresh in the morning for 
him to bring for lunch. We will buy groceries in the morning and cook for him. He will eat some at home and bring some to eat at the store, and he won't eat leftovers. We will have conversations like this: "QB, eat some of this." "No, I won't." "Why not?" "Because it's from yesterday." He only eats freshly cooked food.

Q: Where does he go when he goes out by himself?

QB's father: He is pretty adventurous. Changning Library is close to Furongjiang Road which is easy to get to. He can just take bus Line 71 which stops right in front of the library. He often goes there himself to read illustrated books.

Q: Does he check out the books to bring home?

QB's father: He does, but he won't read them at home. He used to borrow books from school and from Changning Library, too. He even has a library card. A couple of times he checked out science books on building model tanks and planes. He often buys model cars, planes, and tanks and assembles them at home and displays the models in his room. He is quite into that. Overall, he isn't doing bad. There are a lot of people doing worse than he is. He is okay, at least he's self-dependent. You can't have unrealistic expectations for him, can you?

He goes to Zhongshan Park and Chenghuang Temple sometimes. He can go to Disney himself, too. He just needs to take subway Line 11. I took him there for the first time. The park wasn't open yet, so we just spent a day wandering around outside the park, and he was so happy. He went on his own later, twice at least. It's easy to go there, just Line 11 all the way to the terminal. When we took him out, we took the subway all the time. We would ride to People's Square, then go to the pedestrians-only area or to the Bund. We would tell him the directions and he could remember them all. Now if we leave him out there somewhere, he can find his way home and we won't be worried about that at all.

We don't take him out as much now since he works. But he will go out himself. He has 2 days off, right? Tuesday and Wednesday. So he will go out whenever he is in the mood.

On his day off last week, he said it was boring staying home, so I asked him to go out for fun on his own. He said he wanted to go to the Oriental Pearl and I encouraged him to go. He said it costs more than 200 yuan to visit the topmost globe of that place. I have never been to that globe myself; I only visited the middle one. And he never went that high on any school trip. There's an aerospace cabin up there as well as an aerial restaurant, and he went to both places and spent a whole day there. That's what we do with him now. He spends the money he makes on himself and he can support himself. After pension deductions, he makes a little over 2,000 yuan, around 2,200 or 2,300 yuan which is enough to live on for him. That's life for him. It will be very difficult for him to find dates or get married. Him being the way he is, I don't know who will marry him unless she has a disability too.

Q: So he has no problem taking care of himself in daily life?

QB's father: Of course not. You know people in their twenties nowadays. How many of them can do laundry or cook? Not many. And we don't expect that of him anyway.

Q: How do the relatives see him? 
QB's father: It doesn't matter how they see him. We have no choice anyway, having a kid like him. The relatives don't have much to say about it.

For his sake, I decided not to have a kid of my own. After I married his mom, she got pregnant, but we discussed it and she had an abortion more than 2 months into the pregnancy.

To tell you the truth, back then, I didn't want another kid myself. What would I do if the kid had the same IQ as QB? It would be fine if the kid was like me, but what if the kid was like my wife? That would have been the end of the world and given me so much more pressure. So I struggled about it and decided against having another kid.

I am still trying to justify my decision sometimes. I have six siblings. My oldest brother has a daughter, so does my second oldest brother. My third oldest brother has no kid because the wife can't have kids. My younger brother and my oldest sister have one daughter each. My second oldest sister has a son but he doesn't carry our family name. Most of the grandkids are girls, so why would I not want to have a kid? I wanted a son to carry on the family heritage which has now been discontinued. I was back and forth on this one and eventually decided against having a kid of my own, because I would have been done for if the kid had even worse disability than QB. What if the kid had cerebral palsy or deformed feet? That would have been disastrous and totally consuming for me. I thought about it and gave up the idea. If my wife had not had that abortion, the kid would be 16 or 17 now.

Sometimes I feel like I've picked the short straw in life. My two older brothers advised me to have a kid of my own and I couldn't exactly tell them my own reasoning. So I just resigned myself to raising my wife's son. Even though he is not my biological son, I have done my best with him and I am sure he knows that. It's up to him how he is going to treat me in the future. If he has a good heart, he will treat me nice. Otherwise I am okay too, because after all, he is not my biological son and it will be normal if he does not treat me nice. I take it really easy. I just want to live a good life myself and to see him happy. He can support himself now, so that's good enough for me.

\section{What Happens When the Parents Grow Old?}

Q: So he can live independently now?

QB's father: Kind of, except that we will still have to teach him laundry and cooking. Actually, he does know what to do but doesn't want to do it. Sometimes I would buy groceries including pork and tofu and ask him to cook one dish, but he would refuse to do it. I would say, "Let me teach you what to do. Cut the tofu into chunks and shred the pork. Marinate the pork, pour some oil into the pan and stir fry the pork first." He knows the procedures, but he just won't cook for you.

We can still take care of him now. We don't exactly live a luxurious life, but at least he is doing well at Papa John's. What happens down the road, however? I am already 62 , so how do I take care of him when I can't even walk? I won't be able 
to take care of him and that's my biggest worry now. I would like to find a wife for him, but the problem is that no good girl would want him. People like him have no hope of getting married. If you get someone for him whose IQ is the same as or even lower than his, the two of them will be done for. How can the two of them have any kind of family life? They won't know what to do at all. If one of them knows how to cook or do laundry, then maybe they can have some resemblance of a family life.

Someone told me not to worry about it at all. Once we get old, we can just move to a nursing home and wash our hands of him. Just leave him an apartment and some money, right? What else can we do? (Lost in thoughts) My original thinking was to hand him over to his biological father after we get old. Just ask that dad to take him home so we won't have to worry about anything.

Q: Do you talk to his schoolmates' parents, like his good friends' parents, about plans for the future?

QB's father: No, no. We only chatted sitting together at the parent-teacher conferences. We would never call each other up to chat outside the conferences or visit each other at home.

At both the 9-year-curriculum school and the vocational school, there were several parent-teacher conferences each year including at the beginning and end of the year. The teacher would review what's going on with the students, then make suggestions to the parents and explain expectations for the students, then ask the parents what suggestions they might have for the school. After all of that, the parents would have the freedom to talk to each other.

Q: Has he ever thought about having a family of his own?

QB's father: No, never. His mind probably hasn't progressed to that stage yet. He comes home from work now and all he does is computer and cell phone, consuming endless data. I paid more than 300 yuan for his data last month. He plays games non-stop and can use up more than 300 yuan in data per month. When he takes a break at work, he will just sit there and play games since he has nothing else to do. When he comes home, he plays games on his computer. Playing games is all he does.

Q: Do you talk to him about the future?

QB's father: No, we haven't, since he is still young. I had wanted to visit his teacher and see if there's any female schoolmate whose disability isn't that bad. Such a girl could have been a good match for him, since they were from the same school. It would be near impossible for him to find anyone out there and he would have had a slightly better shot at it at school. Out there in the real world, who would want him once his intellectual disability is known? Who would want someone like him with a disability certificate? You can't exactly hide it, because even if you succeed at it, eventually there will be fights which can even lead to divorce. So you have to tell people upfront, and people in their right mind will know, as soon as they see QB or talk to him, what kind of IQ he has. He isn't like us average people. It will be very difficult for him. That's why I figured that maybe the teacher could introduce some girl to him from the same grade at school with a similar IQ as his, granted that her parents agreed. What can I do? If only someone could tell me what to do with QB the way he is.

Q: To wrap up, what expectations do you have for the government? 
QB's father: I have no expectations for the government. But I do hope that QB's job can be a stable one so that he can continue to support himself.

\section{Interview with QB's Co-Worker}

Interviewee: Restaurant manager

Interviewer and writer: Jiaying Xiao

Interview date: January 16, 2017

Interview place: Restaurant where QB works

Q: How's QB at work? Is he a dedicated worker?

Manager: He is good. He listens well and does a good job, whatever you ask him to do.

Q: What does he do at work?

Manager: He makes appetizers and drinks, and he slices pizzas. He can do everything except for kneading and tossing dough, which needs training and might be technically too difficult for him.

Q: Can you be more specific about making appetizers?

Manager: All of the appetizers are already half-cooked, so he just needs to put them in the oven whenever orders come in. He doesn't have to add ingredients, so making appetizers is not a problem for him. He works in the kitchen and doesn't interact with customers.

Q: How does he get along with his co-workers?

Manager: He gets along very well. He has been working here for quite a few years. I joined more than 3 years ago, and he had worked here for more than a year when I joined.

Q: How's your personal relationship with him?

Manager: We only interact as far as work goes and hardly have any personal relationship. He has good relationships with his co-workers.

Q: What do you think of his personality?

Manager: He doesn't do well with strangers. When you meet him for the first time, he won't be able to express himself well. He doesn't communicate well with strangers, but with people he knows like us, he can communicate.

Q: What do you normally talk about with him?

Manager: We talk about eating out. He plays games, so he talks to his co-workers about cell phone games. He isn't allowed to take out his phone during work hours, so he will talk to them when he takes breaks about games he has played. Other than that, I haven't heard him talk about much else. He doesn't really stand out that much, because our company has a lot of employees like him. There is indeed some gap between them and people without disabilities, but if you really make the effort to teach them something, they will get it. I think he is great. He listens when I talk to him and does a good job and doesn't make mistakes. Overall, he is doing well at 
work. I have no unrealistic expectations of him, and whatever I ask him to do now, he does it well.

Q: Did he acquire the skills here at the store or had he been trained at the school before coming here?

Manager: He learnt on the job. For example, there are formulas for the products we have, and employees learn about the formulas at the store. There's another employee being cared for at the store who works in the dining area. He is more outgoing and can strike up a conversation with anyone. And appearance-wise, there's almost no difference between him and people without disabilities. QB is more of an introvert.

\section{Interview with Mr. QB}

Interviewee: Mr. QB

Interviewer and writer: Jiaying Xiao

Interview date: January 16, 2017

Interview place: Restaurant where QB works

Q: What do you normally do at work?

QB: I work my shifts and clean up the place. I make appetizers by baking them on trays. I also make baked rice by adding the ingredients and baking everything in the oven and taking the rice out when it's done. I also make drinks, including Cola, Sprite, and lemon tea. I have to shake some of the drinks and use soda sometimes. I mix the drinks.

Q: What do you think of the co-workers here? Are you happy being with them? I heard from your manager that you will talk to them about games. What kind of games?

QB: I am happy being with them. The games are XXL, PVP, and Pokémon.

Q: Do you think you are doing well at work? Do you make mistakes?

QB: I am doing well. I make mistakes sometimes.

Q: What do you do when you make mistakes?

QB: The products that I make mistakes with can be sold at a discount. And I will just make sure I don't make the same mistakes again.

Q: Are you happier now at work or were you happier when you were going to school?

QB: I was happier when I was going to school. I would go to school and play on the cell phone when I wasn't in class.

Q: What's the biggest difference between when you were going to school and now?

QB: I had more freedom when I was going to school and life was easier. I am supervised at work.

Q: The teachers didn't supervise you at school?

QB: They did, of course.

$\mathrm{Q}$ : What were you taught in class? 
QB: Math and Chinese. I don't remember exactly what.

$\mathrm{Q}$ : Were you naughty at school?

QB: I was sometimes, and the teacher would give me a talk.

Q: Did you play tricks on other kids?

QB: No. I always behaved.

Q: Did the school organize any activities that you still remember well now?

QB: School carnivals where every class had games or other fun going on.

Q: Do you remember which teacher was your favorite?

QB: I remember all the teachers. I have had three teachers and I liked Ms. Zhuang best. She danced in class and was really beautiful when she danced.

Q: How did you come to work today?

QB: I took the bus.

Q: Was it crowded on the bus?

QB: No, not at this hour and some of the buses had no passengers at all. If I leave home at a later time, the bus can get crowded sometimes.

Q: Have you ever been late for work?

QB: I was late before, but not anymore.

$\mathrm{Q}$ : Were you late when you first started working?

QB: No.

$\mathrm{Q}$ : When were you late then?

QB: (Thinking for a long time) I am seldom late.

Q: What do you normally do on your days off?

QB: I have Tuesday and Wednesday off. I stay home on my days off to play games on the computer, like Pokémon and Kaixin001.

Q: You will need friends to play Kaixin001. Are the friends online friends or friends in real life?

QB: Online friends.

Q: Do you go out for fun?

QB: Within Shanghai. I go to Zhongshan Park and Longemont Shopping Mall to buy things, food actually.

Q: What's your favorite food?

QB: I like drinks including milk tea.

Q: Have you been to Disney?

QB: I went during the trial phase.

Q: Was it fun?

QB: Not really. It was during the trial phase and the place wasn't officially open yet.

Q: Did you go into the theme park or just tour the outside?

QB: Just the outside. I went with my dad and the place wasn't officially open yet.

$\mathrm{Q}$ : Do you want to go again?

QB: Not really. It's too expensive.

Q: Have you ever traveled outside Shanghai?

QB: I have not been outside Shanghai. I have always stayed close to Shanghai.

Q: Do you have a favorite place to go to?

QB: Chenghuang Temple where there are a lot of people. 
Q: So you like places with a lot of people? Do you feel happy being with a lot of people?

QB: Right.

Q: There are lit lanterns at Chenghuang Temple during every Lantern Festival. Have you ever seen those lanterns?

QB: No. Too many people to get around anywhere.

Q: What do you normally do during Chinese New Year? It's just around the corner.

QB: I stay home most of the time and go out sometimes.

Q: Do you visit relatives?

QB: No.

Q: Is it time to work now? Are you all set?

QB: Yeah, I already punched in.

\section{Observation of QB at Work}

Observation date: 11:00-20:00, January 16, 2017

Observation place: Restaurant where QB works

Observer and writer: Jiaying Xiao

\begin{tabular}{l|l|l}
\hline Time & What QB did & Remarks \\
\hline $10: 50$ & Cleaned up and got ready for work & \\
\hline $11: 00$ & Started working & \\
\hline $11: 08$ & $\begin{array}{l}\text { Made spaghetti (added ingredients } \\
\text { and put the spaghetti in the oven) }\end{array}$ & \\
\hline $11: 11$ & Transferred cooked spaghetti to a plate & \\
\hline $11: 18$ & Made spaghetti & \\
\hline $11: 20$ & Made spaghetti & \\
\hline $11: 27$ & Transferred cooked spaghetti to a plate & \\
\hline $11: 33$ & $\begin{array}{l}\text { Made appetizers (added ingredients } \\
\text { and put the appetizers in the oven) }\end{array}$ & \\
\hline $11: 48$ & Made pizza (put the pizza in the oven) & \\
\hline $11: 55$ & Fetched takeout orders & \\
\hline $12: 01$ & Made appetizers & \\
\hline $12: 10$ & Made spaghetti & $\begin{array}{l}\text { Talked with a co-worker while } \\
\text { checking single food items being } \\
\text { made }\end{array}$ \\
\hline $12: 21$ & Boxed takeout orders & \\
\hline $12: 30$ & Made spaghetti &
\end{tabular}


(continued)

\begin{tabular}{|c|c|c|}
\hline Time & What QB did & Remarks \\
\hline $12: 43$ & Handed takeout orders to the manager & \\
\hline $12: 52$ & Made spaghetti & \\
\hline 13:03 & Made appetizers & \\
\hline 13:12 & Made drinks & \\
\hline 13:19 & Made spaghetti & \\
\hline 13:25 & Refilled ingredients & \\
\hline $13: 33$ & Organized work counters & \\
\hline 13:50 & $\begin{array}{l}\text { Made baked rice (added ingredients } \\
\text { and put the rice in the oven) }\end{array}$ & \\
\hline 14:02 & Fetched takeout bags & \\
\hline $14: 15$ & Packaged takeout orders & \\
\hline $14: 25$ & Made baked rice & \\
\hline $14: 30$ & Made drinks & \\
\hline $14: 36$ & Delivered coffee & \\
\hline $14: 38$ & Delivered tea & \\
\hline 14:41 & Delivered coffee and tea & \\
\hline $14: 48$ & Made drinks & \\
\hline 15:00-17:00 & Took a break & $\begin{array}{l}\text { When he was on break, QB either } \\
\text { played on the cell phone or talked to } \\
\text { co-workers about cell phone games }\end{array}$ \\
\hline 17:16 & Fetched takeout orders & \\
\hline $17: 23$ & Made spaghetti & \\
\hline $17: 32$ & Made spaghetti & \\
\hline $17: 41$ & Made spaghetti & \\
\hline 17:50 & Made baked rice & \\
\hline 17:56 & Made appetizers & \\
\hline 18:04 & Made drinks & \\
\hline 18:17 & Made appetizers & \\
\hline 18:26 & Made drinks & \\
\hline 18:35 & Made spaghetti & \\
\hline 18:42 & Made drinks & \\
\hline 18:45 & Made spaghetti & \\
\hline 18:55 & Made spaghetti & \\
\hline 19:03 & Made spaghetti & \\
\hline 19:11 & Made appetizers & Chatted with co-workers \\
\hline $19: 26$ & Made spaghetti & $\begin{array}{l}\text { Talked with a co-worker while } \\
\text { checking single food items being } \\
\text { made }\end{array}$ \\
\hline
\end{tabular}


(continued)

\begin{tabular}{l|l|l}
\hline Time & What QB did & Remarks \\
\hline 19:39 & Cleaned up counters & \\
\hline $20: 00$ & Left for the day & \\
\hline
\end{tabular}

Translated by Cissy Zhao

Edited by Andy Boreham and Zijian Chen

Open Access This chapter is licensed under the terms of the Creative Commons Attribution 4.0 International License (http://creativecommons.org/licenses/by/4.0/), which permits use, sharing, adaptation, distribution and reproduction in any medium or format, as long as you give appropriate credit to the original author(s) and the source, provide a link to the Creative Commons license and indicate if changes were made.

The images or other third party material in this chapter are included in the chapter's Creative Commons license, unless indicated otherwise in a credit line to the material. If material is not included in the chapter's Creative Commons license and your intended use is not permitted by statutory regulation or exceeds the permitted use, you will need to obtain permission directly from the copyright holder.

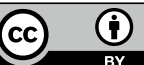

